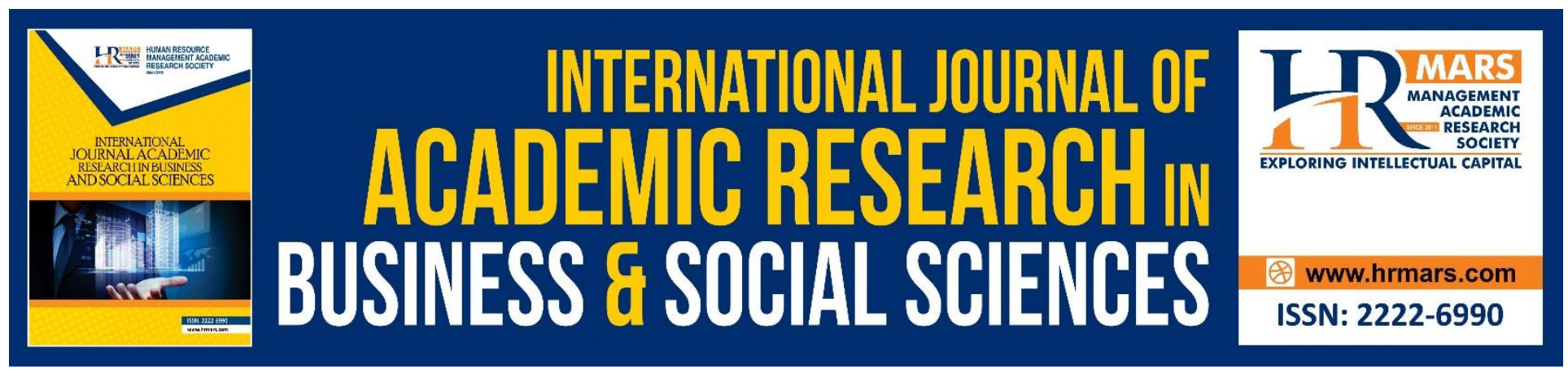

\title{
Teaching at the Times of COVID-19: Inferences and Implications for Higher Education Pedagogy
}

\section{Thanassis Karalis, Natassa Raikou}

To Link this Article: http://dx.doi.org/10.6007/IJARBSS/v10-i5/7219

DOI:10.6007/IJARBSS/v10-i5/7219

Received: 01 April 2020, Revised: 30 April 2020, Accepted: 19 May 2020

Published Online: 22 May 2020

In-Text Citation: (Karalis \& Raikou, 2020)

To Cite this Article: Karalis, T., \& Raikou, N. (2020). Teaching at the Times of COVID-19: Inferences and Implications for Higher Education Pedagogy. International Journal of Academic Research in Business and Social Sciences, 10(5), 479-493.

Copyright: (C) 2020 The Author(s)

Published by Human Resource Management Academic Research Society (www.hrmars.com)

This article is published under the Creative Commons Attribution (CC BY 4.0) license. Anyone may reproduce, distribute, translate and create derivative works of this article (for both commercial and non-commercial purposes), subject to full attribution to the original publication and authors. The full terms of this license may be seen at: $\underline{\text { http://creativecommons.org/licences/by/4.0/legalcode }}$

Vol. 10, No. 5, 2020, Pg. 479 - 493

http://hrmars.com/index.php/pages/detail/IJARBSS

JOURNAL HOMEPAGE

Full Terms \& Conditions of access and use can be found at http://hrmars.com/index.php/pages/detail/publication-ethics 


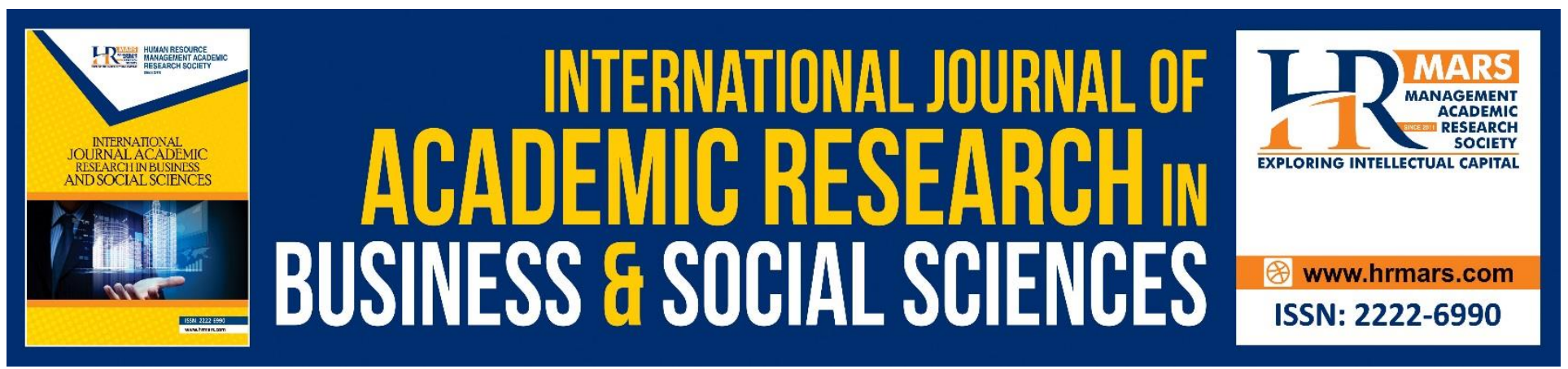

\title{
Teaching at the Times of COVID-19: Inferences and Implications for Higher Education Pedagogy
}

\author{
Thanassis Karalis \\ Professor of Lifelong Learning and Adult Education, University of Patras/Greece. \\ Email: karalis@upatras.gr
}

Natassa Raikou

PhD, Teaching Staff, University of Patras/Greece \& Tutor/Counselor, Hellenic Open University.

Email: araikou@upatras.gr

\begin{abstract}
In our study, conducted during the first two months of the COVID-19 pandemic in Greece, we trace the instant effects of the crisis conditions on the university education. We examine the case of a Department of Education at the University of Patras, in order to investigate the students' assumptions and emotions on the sudden shift to online teaching, in the frame of two academic courses during crisis. Having in mind that University of Patras was one of the first institutions in Greece that responded to the lockdown and moved promptly to the shift to distance learning, we designed a questionnaire with open-ended and closed-ended questions that was filled in by 103 students of the specific Department. The questions refer to students' emotions and their motives of participation in the educational programme, activated due to the current conditions, and whether they foster or prevent the learning process. Our aim was not to compare the two different ways of teaching (online and face to face) but to investigate the lessons learned by this experience and the implications to higher education pedagogy. The results indicate specific points of interest on teaching and learning in higher education, therefore, the necessity of evolving university pedagogy is emerging.
\end{abstract}

Keywords: University Pedagogy, Higher Education Pedagogy, Online Learning, COVID-19 Pandemic, Emergency Remote Teaching.

\section{Introduction}

COVID-19 pandemic started becoming very serious for higher education after the $20^{\text {th }}$ of March 2020, when, according to the data by UNESCO (UNESCO, 2020) more than 1.3 billion learners of all levels of education in 142 countries are affected by the lockdown. Being proactive for the oncoming serious situation, UNESCO urged governments all around the world to take measures in order to restore educational function to the best possible extent (Owusu-Fordjour, Koomson, \& Hanson, 2020). Being aware of the inequalities existing both within societies and among different countries, this appeal concerned undertaking all the possible measures and not only the ones based on ICT (Information 
and Communication Technologies). According to the statement of the Director General Audrey Azoulay (Huang, Liu, Tilli, Yang, \& Wang et al., 2020, p. iii): “We are entering uncharted territory and working with countries to find hi-tech, low-tech and no-tech solutions to assure the continuity of learning". The situation, according to other international organizations (see for example Reimers \& Schleicher, 2020), was characterized as a disruption and mostly it was considered an emergency. In other words, the situation was considered as a crisis and a disruption of the normality and the solutions that had to be given were not solutions for the provision of education as usually, but rather a response considered necessary to include all means available in every case with one and only objective, that is the restoration of educational function, the communication between teachers and students and the continuity of learning as far as possible (Karalis, 2020).

Given that the situation globally is well-known, we prefer not to further mention any data on the pandemic crisis, but to focus more, on the one hand, on higher education and, on the other hand, on the country and the institution from which the research data presented below have been provided, i.e. Greece and the University of Patras.

\section{Higher Education Responses to Covid-19 Pandemic Crisis in Greece}

In Greece, where this particular study comes from, lockdown was initially local and started on the $5^{\text {th }}$ of March with the closure of the University of Patras, in the wider region of which the first cases of COVID-19 in Greece were detected. In a very short time, the lockdown turned from local into countrywide one week later. The State responded immediately and provided the opportunity to all universities in the country to move teaching online, amending the legal framework for the exceptional circumstances. It is worth noting that according to the Greek Constitution all universities are public and the possibility for distance education was allowed until the recent crisis only to the Hellenic Open University, the historic institution of distance education at tertiary level (Panitsides \& Karapistola, 2020). More or less almost all public universities managed in a relatively short time to provide almost all the courses in distance mode. In the case we are discussing below, the University of Patras (University of Patras Covid-19 Committee, 2020) in just one week was able to offer almost all the theoretical-type courses using a system of distance education, based on (i) synchronous education supported by a teleconference software and (ii) asynchronous education of a Moodle type platform already available before crisis. This immediate reaction and the adjustment described met with the students' acceptance, as, according to the available data $82.6 \%$ of the students thought that the shift to the new system was done in a timely manner, whereas $77.1 \%$ were satisfied with the new way to attend classes. It should be noted that the University of Patras is the third largest university of Greece, with 6 Schools and 35 Departments, where around 35,000 students study at undergraduate and post-graduate level, while the professors and teaching staff are more than 1,300 (op. cit.).

\section{Higher Education Pedagogy in the Day After}

Following the widely known "Dr. Fox Lecture" (Naftulin, Ware \& Donelly, 1973), University Pedagogy or Higher Education Pedagogy begun to emerge as a new field of research in Educational Science and Pedagogy (Raikou, 2019). Research in this new field is mainly based on Adult Education, Information and Communications Technologies (ICT), and Learning Theories (Plota \& Karalis, 2019).

Globally, we are witnessing a very rich dialogue on the day after. As for distance education and its applications in higher education, it could be noted that the emergency solutions may have opened Pandora's box and we are now facing a new reality on which opinions are bipolar, and the two poles 
are Panacea and Armageddon. In the first case, it is believed that since the emergency solutions were efficient to some extent, we should just turn all forms of education, especially those for older ones, into distance education. In the second case, it is believed that introducing ICTs may lead to a disaster for education in the form it is known nowadays. More moderate points of view focus on the complementary role of ICTs and the changes that are considered equally necessary in the traditional approach of teaching (see for example Gannon, 2020). It should be noted, though, that the systems applied were not distance education systems but emergency arrangements and this is why in this paper we are not referring to distance education (see for example Korres, 2017) but emergency education in distance mode or, as it has better been set out, emergency remote teaching (Hodges, Moore, Lockee, Trust \& Bond, 2020).

Starting from this optimistic scenario, i.e. that in a relatively short time, the dispersion of the virus will have been harnessed and social life and consequently Higher Education will have returned to normality, a major issue is what will change in terms of teaching at universities. Taking for granted that universities will carry on functioning to a great extent in the way they have constructed their studies systems until now, the intention of the research presented below is not to investigate the degree of adequacy of the solutions given, since, after all, the situation was characterized as an emergency, nor to find out if professors or students wish the complete transformation of the higher education institutions into distance education institutions. Here, we mostly focus on the analogues between face to face teaching and distance education modes (Karalis \& Koutsonikos, 2003; Darwish, Ahmed, \& Pahi, 2020), but also on the fact that the form of higher education up to this point constitutes a prime area for the development of social skills and much more of critical thinking and critical reflection skills (Raikou \& Karalis, 2011).

However, we should take into consideration that the exposure, both of professors and students, to such a large-scale experience, will obviously have reshaped their demands, expectations and also the overview they have of their studies. The focal point of this research is the lessons learned for the mode of studies, the teaching methods and naturally the degree of penetration of the ICTs in order to enhance the work done in classroom and face to face teaching.

\section{Methodological Issues}

As it has already been mentioned, the aim of this study is to highlight, on the one hand, the emotions the students experienced during the first crucial period of online shift, emphasizing on distancing from their familiar environment, the differences (positive and negative) with the previous environment, the content of this experience and the deficiencies they observed in relation to the way classes were conducted up until that point. We have put emphasis on reflective questions asking from respondents in some cases to rationalize their answers in the light of their experience.

The research was carried out in two courses of the Department of Educational Sciences and Early Childhood Education, so the respondents are student teachers. This means that they have the conceptual framework for the main fields of education, as all participants were in the last two years of their studies. One course was about Planning and Evaluation of Adult Education Programs, while the other one was about Reflection on Practicum.

The questionnaire was completed online by 103, after they had already attended four of the meetings in each of the aforementioned courses with teleconference and had worked on assignments in the asynchronous education system, so they already had a quite comprehensive experience of attending under the new system. The questionnaire consisted of thirteen questions; six of them of closedended type (including in total 34 items) in a Likert-type scale (not at all, a little, quite, much and very 
INTERNATIONAL JOURNAL OF ACADEMIC RESEARCH IN BUSINESS AND SOCIAL SCIENCES

Vol. 10, No. 5, May, 2020, E-ISSN: 2222-6990 @ 2020 HRMARS

much) and seven open-ended questions. It was a methodological choice that the open-ended questions came first so that the respondents would not be influenced by the specific items of the closed-ended questions which followed.

\section{Presentation of Findings}

Based on the emotions that arose when the closure of university was announced due to the pandemic of COVID-19 (Table 1), the majority of students felt negative emotions (77.7\%), which mainly included stress, anxiety and sadness:

"Anxiety and concern about what will happen to the semester, the courses and the placement."

"Sadness mainly because it's the last semester I would attend classes at university."

Some students felt mixed emotions (13.6\%), which included joy and relief due to the fact that they would not have obligations at the University but at the same time (or immediately after) concern and sadness about what was going to happen to their studies.

"On the one hand I was worried, afraid, since closing the university was not a good sign at all,

but on the other hand, to be honest, I said to myself at least we'll get some sleep tomorrow." Finally, the lowest percentage (8.7\%) experienced positive emotions of joy and relief.

"Of course, I was glad believing it would be something temporary, like for a week."

Table 1: Students' emotions initially (upon the closure of the University) and afterwards (during online education)

Negative emotions Positive emotions Mixed emotions Total \%

\begin{tabular}{c|cccc}
\hline Initially & $80(77.7 \%)$ & $9(8.7 \%)$ & $14(13.6 \%)$ & 100 \\
Afterwards & $48(46.6 \%)$ & $39(37.9 \%)$ & $16(15.5 \%)$ & 100
\end{tabular}

In particular, in terms of the intensity of the dominant emotions when the university closed, we can see that intense anxiety (much/very much) about when and how the studies will be completed was shared by $90.3 \%$ of the participants, curiosity about what will happen by $86.4 \%$, fear of the possibility of non-continuation of studies by $83.5 \%$, sorrow for the interruption of studies by $68 \%$ and joy that no classes were held by $19.4 \%$. On the contrary, $99 \%$ of the participants showed no or little indifference. 
INTERNATIONAL JOURNAL OF ACADEMIC RESEARCH IN BUSINESS AND SOCIAL SCIENCES Vol. 10, No. 5, May, 2020, E-ISSN: 2222-6990 @ 2020 HRMARS

Table 2: Intensity of the students' emotions initially (upon the closure of the University)

Initial Emotions

\begin{tabular}{|c|c|c|c|c|c|c|c|c|c|c|c|c|}
\hline \multirow{2}{*}{ Initial Emotions } & & & & & & & & & & & & \\
\hline & $\mathbf{N}$ & $\%$ & $\mathbf{N}$ & $\%$ & $\mathbf{N}$ & $\%$ & $\mathbf{N}$ & $\%$ & $\mathbf{N}$ & $\%$ & $\mathbf{N}$ & $\%$ \\
\hline $\begin{array}{l}\text { Anxiety about when } \\
\text { and how studies will be } \\
\text { completed }\end{array}$ & 0 & 0.0 & 4 & 3.9 & 6 & 5.8 & 18 & 17.5 & 75 & 72.8 & 103 & 100 \\
\hline $\begin{array}{l}\text { Curiosity, about what } \\
\text { will happen }\end{array}$ & 0 & 0.0 & 7 & 6.8 & 7 & 6.8 & 34 & 33.0 & 55 & 53.4 & 103 & 100 \\
\hline $\begin{array}{l}\text { Fear, for the possibility } \\
\text { of non-continuation of } \\
\text { studies }\end{array}$ & 2 & 1.9 & 6 & 5.8 & 9 & 8.7 & 21 & 20.4 & 65 & 63.1 & 103 & 100 \\
\hline $\begin{array}{l}\text { Sorrow, over the } \\
\text { interruption of studies }\end{array}$ & 3 & 2.9 & 9 & 8.7 & 21 & 20.4 & 35 & 34.0 & 35 & 34.0 & 103 & 100 \\
\hline $\begin{array}{l}\text { Joy, at the classes not } \\
\text { being held }\end{array}$ & 35 & 34.0 & 25 & 24.3 & 23 & 22.3 & 12 & 11.7 & 8 & 7.8 & 103 & 100 \\
\hline $\begin{array}{l}\text { Indifference, because it } \\
\text { did not bother me }\end{array}$ & 98 & 95.1 & 4 & 3.9 & 1 & 1.0 & 0 & 0.0 & 0 & 0.0 & 103 & 100 \\
\hline
\end{tabular}

When online classes started, $60.2 \%$ of them stated a clear change of emotions, mainly towards a positive direction:

"The initial stress turned into relief as all along I stayed in another city and combined with the fact that I am working, distance online courses was a great way not to lose the semester and especially for those of us who lost theoretical-type courses due to distance and obligations." "After the stress, I now feel optimistic that everything will go well regarding the lessons, due to the new way of learning."

"My emotions have changed from the initial ones I had when I heard that universities are closing. They changed for the better when I experienced e-learning and, to my surprise, I found that there are many nice possibilities in this country and people who are trained to a very good degree, facts that filled me with hope, optimism for something better."

According to Table 1, we notice that negative emotions decreased significantly (46.6\% from $77.7 \%$ ), with a corresponding increase in positive emotions (37.9\% from $8.7 \%$ ), while mixed emotions did not show a significant change (15.5\% from 13.6\%). From their responses a reduction in stress and an increase in optimism and joy emerge:

"Optimism as my Department has informed me that the semester will not be lost, and our teachers have helped us a lot with our tasks and with their understanding of the problems that arise."

"As the days go by and I try to respond to the online courses, I start to feel more secure and more positive, optimistic emotions, in general, about the completion of the academic year." 
INTERNATIONAL JOURNAL OF ACADEMIC RESEARCH IN BUSINESS AND SOCIAL SCIENCES

Vol. 10, No. 5, May, 2020, E-ISSN: 2222-6990 @ 2020 HRMARS

The majority of the students feel joy, pleasure and comfort (80\%) about the new way of online education, in contrast to the $20 \%$ who experience difficulties or are negative towards this way of education:

"I'm not used to nor am I familiar with this whole situation, nevertheless it's a pleasant environment."

"Our teachers also played a role in making us feel good and comfortable in our new environment. Flexible!"

"I realized the usefulness of technological evolution. In general, I'm not very close to technology, in some things I prefer old ways, e.g. printed books and not electronic ones. Of course, staring 6 hours in a row at a computer or mobile phone is quite tiring for our eyes. In addition, since I'm a person who takes notes because that's how I pay more attention to the class, it's a little harder. We have to get used to it because it seems to be the best possible way. "

"Very familiar and perhaps a little closer to fellow students and teachers (given that we work towards the same goal) than in a real classroom."

"It certainly makes it much easier for people who already wanted online courses before quarantine, but I don't think they can replace regular lectures in the classroom."

In particular, as for the intensity of dominant emotions during online training (Table 3), we can observe that intense relief (much/very much) because the semester will not be lost, was expressed by $95.2 \%$ of the participants, joy at the continuity of the lessons by $91.3 \%$, curiosity about how to continue their studies by $70.9 \%$, while pleasure that no commuting is required for the course as well as enthusiasm for the new experience was expressed by $70.9 \%$. In contrast, $80.6 \%$ of the participants showed no or little disappointment with the new educational environment. 
INTERNATIONAL JOURNAL OF ACADEMIC RESEARCH IN BUSINESS AND SOCIAL SCIENCES

Vol. 10, No. 5, May, 2020, E-ISSN: 2222-6990 @ 2020 HRMARS

Table 3: The intensity of students' emotions during online education

\begin{tabular}{|c|c|c|c|c|c|c|c|c|c|c|c|c|}
\hline \multirow{2}{*}{$\begin{array}{l}\text { Emotions during } \\
\text { online education }\end{array}$} & \multicolumn{2}{|c|}{ Not at all } & \multicolumn{2}{|c|}{ A little } & \multicolumn{2}{|c|}{ Quite } & \multicolumn{2}{|c|}{ Much } & \multicolumn{2}{|c|}{ Very much } & \multicolumn{2}{|c|}{ Total } \\
\hline & $\mathbf{N}$ & $\%$ & $\mathbf{N}$ & $\%$ & $\mathbf{N}$ & $\%$ & $\mathbf{N}$ & $\%$ & $\mathbf{N}$ & $\%$ & $\mathbf{N}$ & $\%$ \\
\hline $\begin{array}{l}\text { Relief at not losing } \\
\text { the semester }\end{array}$ & 0 & 0.0 & 1 & 1.0 & 4 & 3.9 & 11 & 10.7 & 87 & 84.5 & 103 & 100 \\
\hline $\begin{array}{l}\text { Joy at the } \\
\text { continuity of the } \\
\text { lessons }\end{array}$ & 0 & 0.0 & 1 & 1.0 & 8 & 7.8 & 50 & 48.5 & 44 & 42.7 & 103 & 100 \\
\hline $\begin{array}{l}\text { Curiosity about } \\
\text { how studies will } \\
\text { continue }\end{array}$ & 2 & 1.9 & 10 & 9.7 & 18 & 17.5 & 36 & 35.0 & 37 & 35.9 & 103 & 100 \\
\hline $\begin{array}{l}\text { Pleasure at not } \\
\text { having to commute } \\
\text { to attend classes }\end{array}$ & 6 & 5.8 & 12 & 11.7 & 21 & 20.4 & 20 & 19.4 & 44 & 42.7 & 103 & 100 \\
\hline $\begin{array}{l}\text { Enthusiasm for the } \\
\text { new experience }\end{array}$ & 3 & 2.9 & 7 & 6.8 & 29 & 28.2 & 24 & 23.3 & 40 & 38.8 & 103 & 100 \\
\hline $\begin{array}{l}\text { Disappointment, } \\
\text { the new } \\
\text { educational } \\
\text { environment does } \\
\text { not work for me }\end{array}$ & 53 & 51.5 & 30 & 29.1 & 17 & 16.5 & 3 & 2.9 & 0 & 0.0 & 103 & 100 \\
\hline
\end{tabular}

Evaluating the online mode of education, in relation to the usual context, they point out some positive and negative characteristics (Tables $4 \& 5$ ). Among the positive characteristics (Table 4), easier participation in the course (65\%) stands out, mainly through the opportunities offered by technology, but also due to the way of communication:

"It's easy to access files on our computer in case we need them."

"Flexible teaching techniques are used for the desired response from the learners."

"I can concentrate more, it's easier for me to take notes."

"It is easier for the shyer students to participate in the course, since there is an opportunity to express their opinion in writing via chat."

"You don't have visual stimuli to distract you, you get the gist."

At the same time, the benefit in time and money is mentioned (Table 4), due to not having to commute (56\%), as well as the comfort of the house (28\%):

"The distance learning courses can be attended by everyone from their home, because we all know that there are parent students who have many obligations. Moreover, the weather conditions don't prevent you from going to class and finally, you are not late."

"Possibly more 'mood' for attending due to more comfort at home."

In addition, it is worth noting that $12.6 \%$ emphasize the fact that classes are not lost, while $11.7 \%$ refer to the familiarity with new teaching methods as a positive element, as well as the flexibility offered by this mode of education as far course attendance and study are concerned:

"Both us, students, and teachers get in touch and learn a new form of teaching, online."

"The new mode of teaching also teaches us more things about technology that we can use in the future." 
INTERNATIONAL JOURNAL OF ACADEMIC RESEARCH IN BUSINESS AND SOCIAL SCIENCES Vol. 10, No. 5, May, 2020, E-ISSN: 2222-6990 @ 2020 HRMARS

"Possibility of a break when I get tired and I can't attend the course."

Table 4: The positive characteristics of online education compared to the usual context

\begin{tabular}{c|lcc} 
A / A & \multicolumn{1}{|c}{ Positive Characteristics } & N & $\%$ \\
\hline 1 & Easier to participate in class & 67 & 65 \\
2 & No need to commute (savings in time \& money) & 58 & 56 \\
3 & Home comfort & 29 & 28 \\
4 & Classes are not lost & 13 & 12.6 \\
5 & Familiarity with new teaching methods & 12 & 11.7 \\
6 & Attending and study flexibility & 12 & 11.7
\end{tabular}

Regarding the negative characteristics that students identify in online education, in relation to the usual educational context (Table 5), the elements mentioned are related to issues of poor communication, cooperation and socialization in the academic context. Specifically, the majority (70.9\%) mentions the lack of personal contact between teacher and students and also among students, the difficulty of concentrating and participating in the class (21.4\%), as well as the lack of physical presence on campus (8.7\%):

"No one can understand your feelings since there is no direct visual contact."

"In the classroom there is more spontaneity in communication between teacher - student

(whereas in distance mode not so much), the teacher cannot observe our reactions, in order to make further clarifications or even questions (not everyone shares his/her questions through the chat)."

"Teachers don't get to know us. It's hard to have excellent communication with someone you don't see. They don't know if there is participation or if half of them are lying in their beds."

"Socialization and interaction with my fellow students are not achieved."

"We don't have this interaction with our teacher and fellow students, and we can't work so smoothly in groups and that also applies to lab courses."

"The absence of immediacy, which exists in the normal classroom, where there is a real contact with the teacher."

"Certainly, there are difficulties that interrupt or alter the way content is presented, resulting in a lack of understanding or wasting valuable time."

Other negative features are the technical difficulties of online education (55.3\%), the long hours in front of the computer (15.5\%) and the lack of logistical infrastructure (10.7\%). 
INTERNATIONAL JOURNAL OF ACADEMIC RESEARCH IN BUSINESS AND SOCIAL SCIENCES Vol. 10, No. 5, May, 2020, E-ISSN: 2222-6990 @ 2020 HRMARS

Table 5: The negative characteristics of online education compared to the usual context

\begin{tabular}{c|lcc} 
A / A & \multicolumn{1}{|c}{ Negative Characteristics } & N & $\%$ \\
\hline 1 & Lack of personal contact & 73 & 70.9 \\
\hline 2 & Technical difficulties & 57 & 55.3 \\
3 & Difficulty concentrating and participating in the class & 22 & 21.4 \\
4 & Too many hours in front of the computer & 16 & 15.5 \\
5 & Lack of logistical infrastructure by some students & 11 & 10.7 \\
6 & Non-physical presence on campus & 9 & 8.7 \\
7 & Work placement and some lab courses are lost & 6 & 5.8 \\
8 & More workload & 6 & 5.8 \\
\hline
\end{tabular}

Regarding the degree of their participation in the courses during the online education, in relation to the usual educational context, the majority (55.3\%) participate more, 35\% the same and $9.7 \%$ less (Table 6). The reasons for greater participation are mainly because there is more time available, without the obligation to commute, while an important element is the fact that the teaching conditions are more favorable and make participation in the class easier:

"I have the ability to attend classes at the touch of a button without having to commute to the University premises."

"It's easier for me to participate through messages."

"I'm shy and even though your name is mentioned, the conversation is impersonal and the whole audience doesn't turn around to stare at you when you raise your hand."

"The prevailing climate is more favorable from my point of view, in the sense that we are all in a common situation, both our professors and we, students, are in the same position and we are called to work together in a common way trying to have a good end result. Therefore, this comes from both sides, there is understanding and a friendly mood on both sides."

Table 6: Degree of participation of students in online education, in relation to the usual educational context

\begin{tabular}{l|cc}
\multicolumn{1}{c}{ Degree of participation in online lessons } & N & \% \\
\hline More & 57 & 55.3 \\
The same & 36 & 35 \\
Less & 10 & 9.7 \\
Total & 103 & 100
\end{tabular}

In particular, comparing the two modes of education, i.e. the usual and the online (Table 7), the majority believe that to a large extent (much/very much) new skills related to distance education are being developed (86.4\%), which are related with the use of technology, as well as with online attendance and participation in class. In addition, they argue that the content of the course is understandable and attendance is easy (73.8\%), the new mode of teaching is interesting (72.8\%), participation in class is great $(70.9 \%)$, and communication with the teacher is satisfactory (66\%). 
INTERNATIONAL JOURNAL OF ACADEMIC RESEARCH IN BUSINESS AND SOCIAL SCIENCES Vol. 10, No. 5, May, 2020, E-ISSN: 2222-6990 @ 2020 HRMARS

Regarding the teaching method of distance education, $58.3 \%$ believe that it largely covers the needs of the course, while $56.3 \%$ believe that the interaction between teacher and students is great. However, the interaction among students is considered less by the participants (32\% much/very much).

Table 7: Degree of development of educational characteristics in online education, in relation to the usual educational context

\section{Educational characteristics of online education}

\begin{tabular}{|lcccccccccccc}
\multicolumn{2}{c}{$\begin{array}{c}\text { Not at } \\
\text { all }\end{array}$} & \multicolumn{2}{c}{ A little } & \multicolumn{2}{c}{ Quite } & \multicolumn{2}{c}{ Much } & \multicolumn{2}{c}{ Very much } & \multicolumn{2}{c}{ Total } \\
\hline $\mathbf{N}$ & $\%$ & $\mathbf{N}$ & $\%$ & $\mathbf{N}$ & $\%$ & $\mathbf{N}$ & $\%$ & $\mathbf{N}$ & $\%$ & $\mathbf{N}$ & $\%$ \\
1 & 1.0 & 5 & 4.9 & 8 & 7.8 & 32 & 31,1 & 57 & 55.3 & 103 & 100 \\
0 & 0.0 & 1 & 1.0 & 26 & 25.2 & 54 & 52.4 & 22 & 21.4 & 103 & 100 \\
0 & 0.0 & 4 & 3.9 & 23 & 22.3 & 40 & 38.8 & 36 & 35.0 & 103 & 100 \\
0 & 0.0 & 6 & 5.8 & 22 & 21.4 & 43 & 41.7 & 32 & 31.1 & 103 & 100 \\
0 & 0.0 & 4 & 3.9 & 26 & 25.2 & 47 & 45.6 & 26 & 25.2 & 103 & 100 \\
0 & 0.0 & 6 & 5.8 & 29 & 28.2 & 42 & 40.8 & 26 & 25.2 & 103 & 100 \\
0 & 0.0 & 6 & 5.8 & 37 & 35.9 & 50 & 48.5 & 10 & 9.7 & 103 & 100 \\
\hline 6 & 5.8 & 30 & 29.1 & 34 & 33.0 & 25 & 24.3 & 8 & 7.8 & 103 & 100 \\
\hline & 1.9 & 10 & 9.7 & 33 & 32.0 & 41 & 39.8 & 17 & 16.5 & 103 & 100 \\
\hline
\end{tabular}

New skills related to distance education are being developed

The content of the course is comprehensible

Attending is easy

The new mode of teaching is interesting

Participation in class is great

\begin{tabular}{|lcccccccccccc}
\multicolumn{2}{c}{$\begin{array}{c}\text { Not at } \\
\text { all }\end{array}$} & \multicolumn{2}{c}{ A little } & \multicolumn{2}{c}{ Quite } & \multicolumn{2}{c}{ Much } & \multicolumn{2}{c}{ Very much } & \multicolumn{2}{c}{ Total } \\
\hline $\mathbf{N}$ & $\%$ & $\mathbf{N}$ & $\%$ & $\mathbf{N}$ & $\%$ & $\mathbf{N}$ & $\%$ & $\mathbf{N}$ & $\%$ & $\mathbf{N}$ & $\%$ \\
1 & 1.0 & 5 & 4.9 & 8 & 7.8 & 32 & 31,1 & 57 & 55.3 & 103 & 100 \\
0 & 0.0 & 1 & 1.0 & 26 & 25.2 & 54 & 52.4 & 22 & 21.4 & 103 & 100 \\
0 & 0.0 & 4 & 3.9 & 23 & 22.3 & 40 & 38.8 & 36 & 35.0 & 103 & 100 \\
0 & 0.0 & 6 & 5.8 & 22 & 21.4 & 43 & 41.7 & 32 & 31.1 & 103 & 100 \\
0 & 0.0 & 4 & 3.9 & 26 & 25.2 & 47 & 45.6 & 26 & 25.2 & 103 & 100 \\
0 & 0.0 & 6 & 5.8 & 29 & 28.2 & 42 & 40.8 & 26 & 25.2 & 103 & 100 \\
0 & 0.0 & 6 & 5.8 & 37 & 35.9 & 50 & 48.5 & 10 & 9.7 & 103 & 100 \\
\hline 6 & 5.8 & 30 & 29.1 & 34 & 33.0 & 25 & 24.3 & 8 & 7.8 & 103 & 100 \\
\hline & 1.9 & 10 & 9.7 & 33 & 32.0 & 41 & 39.8 & 17 & 16.5 & 103 & 100 \\
\hline
\end{tabular}

Communication with the teacher is satisfactory The teaching method of distance learning covers the prerequisites of the course The interaction between teacher and students is great

The interaction among students is great

During the electronic class, what the students think that affects them to a great extent (much/very much) is whether the teacher's camera is on (58.3\%) and whether s/he is able to handle the platform satisfactorily (52.4\%). This is followed by the possibility of cooperation with students (44.7\%), as well as visual communication with fellow students (35\%). 
INTERNATIONAL JOURNAL OF ACADEMIC RESEARCH IN BUSINESS AND SOCIAL SCIENCES

Vol. 10, No. 5, May, 2020, E-ISSN: 2222-6990 @ 2020 HRMARS

Table 8: Influencing factors for the effectiveness of the electronic class

\begin{tabular}{|c|c|c|c|c|c|c|c|c|c|c|c|c|}
\hline \multirow{2}{*}{$\begin{array}{l}\text { Influencing factors for } \\
\text { the effectiveness of } \\
\text { the electronic class }\end{array}$} & \multicolumn{2}{|c|}{ Not at all } & \multicolumn{2}{|c|}{ A little } & \multicolumn{2}{|c|}{ Quite } & \multicolumn{2}{|c|}{ Much } & \multicolumn{2}{|c|}{ Very much } & \multicolumn{2}{|c|}{ Total } \\
\hline & $\mathbf{N}$ & $\%$ & $\mathbf{N}$ & $\%$ & $\mathbf{N}$ & $\%$ & $\mathbf{N}$ & $\%$ & $\mathbf{N}$ & $\%$ & $\mathbf{N}$ & $\%$ \\
\hline $\begin{array}{l}\text { The teacher's camera } \\
\text { should be on }\end{array}$ & 15 & 14.6 & 8 & 7.8 & 20 & 19.4 & 31 & 30.1 & 29 & 28.2 & 103 & 100 \\
\hline $\begin{array}{l}\text { Teacher's deficiencies } \\
\text { in knowledge of } \\
\text { handling the platform }\end{array}$ & 4 & 3.9 & 12 & 11.7 & 33 & 32.0 & 29 & 28.2 & 25 & 24.3 & 103 & 100 \\
\hline $\begin{array}{l}\text { Non-cooperation with } \\
\text { my fellow students }\end{array}$ & 8 & 7.8 & 17 & 16.5 & 32 & 31.1 & 34 & 33.0 & 12 & 11.7 & 103 & 100 \\
\hline $\begin{array}{l}\text { Non-visual } \\
\text { communication with } \\
\text { my fellow students }\end{array}$ & 26 & 25.2 & 16 & 15.5 & 25 & 24.3 & 27 & 26.2 & 9 & 8.7 & 103 & 100 \\
\hline
\end{tabular}

Regarding the ease of asking questions during the class, the majority consider that the chat in the electronic class is much/very much easier (68\%) and is followed closely by the classroom in the usual class (65.1\%). Speaking during the electronic class received $44.7 \%$ of the answers, in terms of the effectiveness that the participants attribute to it to a large extent (much/very much).

Table 9: Effectiveness of the ways of phrasing questions during the lesson

\begin{tabular}{|c|c|c|c|c|c|c|c|c|c|c|c|c|}
\hline \multirow{2}{*}{$\begin{array}{l}\text { Ways of phrasing } \\
\text { questions during the } \\
\text { lesson }\end{array}$} & \multicolumn{2}{|c|}{ Not at all } & \multicolumn{2}{|c|}{ A little } & \multicolumn{2}{|c|}{ Quite } & \multicolumn{2}{|c|}{ Much } & \multicolumn{2}{|c|}{ Very much } & \multicolumn{2}{|c|}{ Total } \\
\hline & $\mathbf{N}$ & $\%$ & $\mathbf{N}$ & $\%$ & $\mathbf{N}$ & $\%$ & $\mathbf{N}$ & $\%$ & $\mathbf{N}$ & $\%$ & $\mathbf{N}$ & $\%$ \\
\hline On chat & 2 & 1.9 & 5 & 4.9 & 26 & 25.2 & 27 & 26.2 & 43 & 41.7 & 103 & 100 \\
\hline In the classroom & 5 & 4.9 & 11 & 10.7 & 20 & 19.4 & 31 & 30.1 & 36 & 35.0 & 103 & 100 \\
\hline Speaking online & 4 & 3.9 & 10 & 9.7 & 43 & 41.7 & 33 & 32.0 & 13 & 12.6 & 103 & 100 \\
\hline
\end{tabular}

Finally, the element that students mention they miss about the university's usual operating mode is mainly social interaction. Specifically, they point out that they are missing the general social interaction on campus much/very much (87.4\%), live communication during the lesson (80.6\%), their fellow students $(70.9 \%)$, as well as teachers $(51.5 \%)$. As far as educational spaces are concerned, $46.6 \%$ point out that they miss the classrooms much/very much, while much less ( $27.2 \%$ much/ very much) the university library. 
INTERNATIONAL JOURNAL OF ACADEMIC RESEARCH IN BUSINESS AND SOCIAL SCIENCES

Vol. 10, No. 5, May, 2020, E-ISSN: 2222-6990 @ 2020 HRMARS

Table 10: Elements of regular education that are missing from online education

\begin{tabular}{|c|c|c|c|c|c|c|c|c|c|c|c|c|}
\hline \multirow{2}{*}{$\begin{array}{l}\text { Elements of regular } \\
\text { education missing } \\
\text { from online education }\end{array}$} & \multicolumn{2}{|c|}{ Not at all } & \multicolumn{2}{|c|}{ A little } & \multicolumn{2}{|c|}{ Quite } & \multicolumn{2}{|c|}{ Much } & \multicolumn{2}{|c|}{ Verymuch } & \multicolumn{2}{|c|}{ Total } \\
\hline & $\mathbf{N}$ & $\%$ & $\mathbf{N}$ & $\%$ & $\mathbf{N}$ & $\%$ & $\mathbf{N}$ & $\%$ & $\mathbf{N}$ & $\%$ & $\mathbf{N}$ & $\%$ \\
\hline Social interaction & 0 & 0.0 & 3 & 2.9 & 10 & 9.7 & 34 & 33.0 & 56 & 54.4 & 103 & 100 \\
\hline $\begin{array}{l}\text { Live communication } \\
\text { during the lesson }\end{array}$ & 4 & 3.9 & 4 & 3.9 & 12 & 11.7 & 36 & 35.0 & 47 & 45.6 & 103 & 100 \\
\hline Fellow students & 10 & 9.7 & 6 & 5.8 & 14 & 13.6 & 40 & 38.8 & 33 & 32.0 & 103 & 100 \\
\hline Teachers & 6 & 5.8 & 9 & 8.7 & 35 & 34.0 & 42 & 40.8 & 11 & 10.7 & 103 & 100 \\
\hline Classrooms & 12 & 11.7 & 9 & 8.7 & 34 & 33.0 & 33 & 32.0 & 15 & 14.6 & 103 & 100 \\
\hline Library & 17 & 16.5 & 21 & 20.4 & 37 & 35.9 & 14 & 13.6 & 14 & 13.6 & 103 & 100 \\
\hline
\end{tabular}

\section{Conclusions}

According to the findings of this study it is clear that at the closure of universities, students were filled with strong negative emotions and, to a small extent, with temporary joy. Upon the beginning of electronic classes, the dominant emotions turned into positive ones, mainly optimism and relief but also enthusiasm for the new experience. The vast majority did not have any difficulty in switching to online teaching, as participation in the class was easier, mainly through the possibilities offered by technology, but also because of the way of communication between the teacher and the students. This conclusion is in accordance with other studies on distance education and e-learning (see for example, Panitsides \& Karapistola, 2020; Pavlis-Korres, 2017). In addition, coming into contact with new ways of teaching excited some participants because of the difference compared to the usual process. As for the negative elements of online education, apart from the technical obstacles that have arisen, they are mainly related to lack of communication and cooperation, as well as the general restriction of social contact in the academic context.

In any case, it is clear that the significant increase in participation in online education is due in part to the particular conditions prevailing during the lockdown because of the pandemic, with more time available and without the obligation to commute to the campus, but also due to teaching conditions, which make it easier to attend and make participation in the lesson easier and more interesting. It should also be taken into account that the mode of teaching was very different from the previous one and, therefore, the students saw it as a new experience, actually based on the means they are used to communicating with, in their daily lives.

In addition, the participants' responses show that through online teaching new skills are developed by the participants, which are directly related to distance learning. In terms of teaching content, the majority consider it to be covered by distance learning as well, but a significant percentage of students do not agree with it, arguing that face to face learning covers the subject being taught to a greater extent.

Regarding the interaction between teacher and students, opinions differ depending on the students' temperament and personal preferences in the way they learn: some students prefer live contact and classroom attendance for both comprehension and participation in the lesson, while others feel more comfortable, concentrate better and express themselves more when participating in a distance course. In particular, during class, the majority believe that chatting during online teaching facilitates 
asking questions as far as possible, with little difference from attending a course in the usual classroom.

In any case, the vast majority agree that collaboration between students is clearly greater in the usual way of education rather than online. Therefore, the latter lags behind on the cooperation and in general the dynamics of the team developed face to face, both in terms of conducting the classes, and in general the social interaction and socialization on campus, an element that strengthens their identity as students and members of a community.

From the above, it can be inferred that each mode of teaching has to offer some strong elements to education, but in no case should it be considered one superior to the other. It is clear that face to face education could in any case be benefited and enriched with elements of online education, since, as it can be seen, students' views are positive towards the latter, while the students find it easy to use ICT. As a result, teaching methods that combine face to face with distance learning can enhance students' interest and participation in the lesson. One such example could be the application of flipped classroom, which can provide even greater classroom interaction and new dynamics in face to face teaching through a focus on experiential situations (Plota \& Karalis, 2019).

The experience of the COVID-19 pandemic, therefore, can serve as a good reason for the renewal and development of teaching and learning in the university context. Relevant research in the field of university pedagogy has so far highlighted this need (Plota \& Karalis, 2019; Raikou, 2019), nevertheless, it is confirmed and given prominence by the current crisis. After all, university is an area that advocates research, progress

and development, therefore the emergence of University Pedagogy as a new scientific field in education is timely and can make a decisive contribution.

\section{References}

Darwish, S., Ahmed, U., \& Pahi, M. H. (2020). Innovative Work Behavior During COVID-19 for Medical Representative in the Pharmaceutical Industry: Test of a Moderation Model in Bahrain. International Journal of Pharmaceutical Research. 12(4), 1927-

1934. doi.org/10.31838/ijpr/2020.12.04.277

Gannon, K. (2020). 4 Lessons from Moving a Face-to-Face Course Online. The Chronicle of Higher Education, Special Issue "Moving Online Now", 24-27.

Hodges, C., Moore, S., Lockee, B., Trust, T., \& Bond, A. (2020). The Difference Between Emergency Remote Teaching and Online Learning. EDUCAUSE Review.

https://er.educause.edu/articles/2020/3/the-difference-between-emergency-remoteteaching-and-onlinelearning?fbclid=IwAR0yiCtV1QE9bUgSjiBxK4JDhSO_ORoBpSs0o6gkju2zimYHc6jWSNfnE1M

Karalis, T. (2020). Planning and evaluation during educational disruption: lessons learned from COVID-19 pandemic for treatment of emergencies in education. European Journal of Education Studies, 7(4), 125-142.

Karalis, T., \& Koutsonikos, G. (2003). Issues and Challenges in Organizing Web-based Courses for Adults. Themes in Education, 4(2), 177-188. Available: https://www.researchgate.net/publication/215576866_Issues_and_Challenges_in_Organizi ng_Web-based_Courses_for_Adults.

Naftulin, D. H., Ware, J. E., \& Donelly, F. A. (1973). The Doctor Fox Lecture: A paradigm of educational seduction. Journal of Medical Education, 48, 630-635. 
INTERNATIONAL JOURNAL OF ACADEMIC RESEARCH IN BUSINESS AND SOCIAL SCIENCES

Vol. 10, No. 5, May, 2020, E-ISSN: 2222-6990 @ 2020 HRMARS

Owusu-Fordjour, C., Koomson, C. K., \& Hanson, D. (2020). The Impact of COVID-19 on Learning - The Perspective of the Ghanaian Student. European Journal of Education Studies, 7(3), 88-101.

Panitsides, E. A., \& Karapistola, A. (2020). Enhancing the role of the Hellenic Open University as a Lifelong Learning Organization: Crossing the Rubicon into the e-learning era. In E. Sengupta, P. Blessinger \& M. Makhanya (eds) Humanizing Higher Education: The Role of Technology. U.K.: Emerald (in press).

Pavlis-Korres, M. (2017). The Positive Effect of Evaluation on Improving E-Learning Courses Addressed to Adults: A Case Study on the Evolution of GSLLLY Courses in Greece over a Decade. Journal of Education and Training Studies, 5 (1), 1-11.

Plota, D., \& Karalis, T. (2019). Organization and implementation of a Flipped Classroom course in the Greek University context. Educational Journal of the University of Patras UNESCO Chair, 6(2), 53-61.

Raikou, N. (2019). Teacher Education at the forefront: Long-term study through the prism of University Pedagogy and Transformative Learning theory. European Journal of Education Studies, 6(3), 88-102.

Raikou, N., \& Karalis, T. (2011). Exploring the potential of Transformative Learning in Higher Education: the development of students' critical thinking through aesthetic experience, $9^{\text {th }}$ International Conference on Transformative Learning, Athens, 28-29 May 2011. In M. Alhadeff-Jones, \& A. Kokkos (eds.), 2011, Transformative Learning in Time of Crisis: Individual and Collective Challenges (pp. 261-267). Athens: Columbia University and Hellenic Open University.

Reimers, F. M., \& Schleicher, A. (2020). A framework to guide an education response to the COVID-19 Pandemic of 2020. OECD. Available:

https://www.hm.ee/sites/default/files/framework_guide_v1_002_harward.pdf.

UNESCO Institute for Statistics Data. (2020). COVID-19 Impact on Education. UNESCO. Available: https://en.unesco.org/covid19/educationresponse.

University of Patras COVID-19 Committee (2020). Second Report of the Committee for the education in the University in COVID-19 situation [in Greek]. Available:

https://eclass.upatras.gr/courses/EE994/ 